\title{
An Alternative Human Development Index Considering Unemployment
}

Mehmet Tolga Taner, Bülent Sezen, Hakan Mıhcı*

\section{Abstract:}

The Human Development Index (HDI) has played an influential role in the debate on human development (HD) for many years. However, no index is perfect and neither is the HDI of the United Nations Development Program (UNDP). This paper aims to construct a new composite index for the development performance of a sample of 30 Organization for Economic Co-operation and Development (OECD) countries by adding a fourth indicator, namely the unemployment index, to the calculation of HDI. The addition of the unemployment factor to the HDI as a new indicator has the potential to make the index more comprehensive and present a suitable approach for assessing the development performance of countries.

Keywords: Development, Human Development, Human Development Index, Unemployment, OECD countries

JEL: 015

DOI: $10.2478 / v 10033-011-0005-z$

\section{Introduction}

During the last twenty years, development has increasingly been defined as HD rather than economic growth, and hence, HD indicators such as life expectancy at birth, school enrolment ratio, literacy rate, gender discrimination and poverty alleviation have largely been employed to determine and measure the level of development.

Until now, normalized measures of life expectancy, literacy, educational attainment, and GDP per capita have been considered the main indicators of HD for all nations. Each plays a different role in HD and are unified to give a measure named the Human Development Index (HDI). It should be indicated that HDI does not measure absolute levels of HD; rather it ranks the countries according to the lowest and highest levels of achievement. The countries are ranked into three groups: low HD (0.000 to 0.499), medium HD (0.500 to 0.799$)$ and high HD (0.800 to $1.000)^{1}$.

The latest reports published in 2009 and 2010, however, have included a fourth group in the analysis and categorize these countries as "very high human development" for index values ranging from 0.900 to 1.000 (UNDP 2010 and 2009).
HDI was first calculated in the United Nations Development Program's (UNDP) Human Development Report (HDR). Since the first publication of this annual report in 1990, the UNDP has sought to explore the concept and improve the measurement of global HD. Nonetheless, over the last 20 years, there has been considerable improvement in many aspects of measuring HD.

$\mathrm{HDI}$ is a simple measure that computes and assigns a

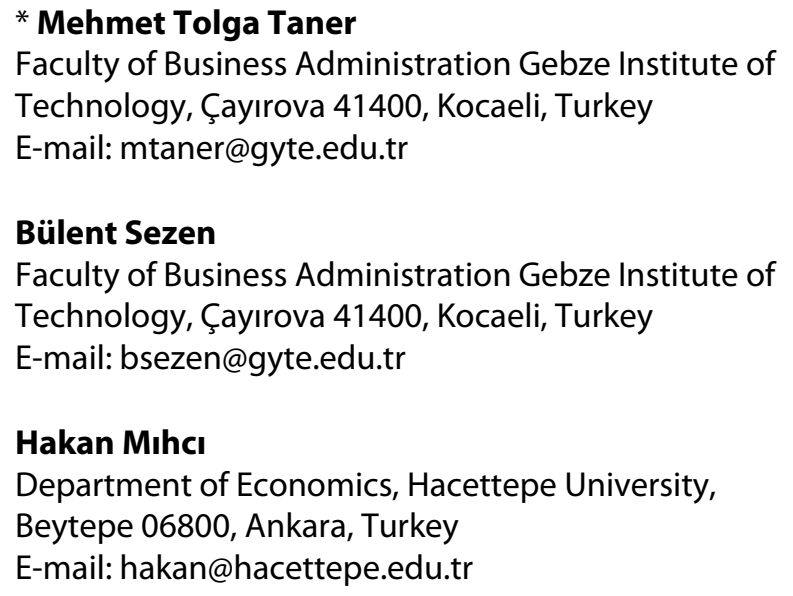

Hakan Mıhcı

Department of Economics, Hacettepe University, Beytepe 06800, Ankara, Turkey

E-mail: hakan@hacettepe.edu.tr 
single, scalar value to each country of the world based on three components of HD. This measure has radically changed the debate on development and deeply influenced the agenda of both researchers and policy makers around the world since it was implemented. Criticisms and proposed alternatives abound, yet the index has managed to maintain its popularity and simplicity with only minor modifications over the years of 1991, 1994, 1995, 1999 and 2010.

The main function of the $\mathrm{HDI}$ is the annual ranking of countries. This ranking may serve primarily as a policy instrument, particularly in highly ranking developed countries. The rankings are often taken too seriously in public discourse. Since the underlying statistics are also uncertain with margins of several percent, the third decimal digit in the HDI is also uncertain, and the ensuing rankings can be at error in several points. Moreover, the rankings are sensitive to all $\mathrm{HDI}$ indicators and their reference minimum and maximum values used for scaling (Lind 2010). Thus, the annual rankings should reflect proper and definite results so that they can serve primarily as a policy instrument, particularly in developed countries.

This paper empirically examines whether the inclusion of an unemployment factor in the HDI would yield a different ranking of nations. It is argued that it is appropriate to modify the HDI by simply adding an unemployment indicator in the index. This Unemployment-adjusted Human Development Index is denoted as HDI-2. OECD countries have been chosen for analysis since unemployment data are not available or sufficiently reliable for other groups of countries in the world.

\section{Theoretical and Empirical Background}

The HDI was developed to measure "the basic concept of HD to enlarge people's choices" (UI Haq 1995). It was also designed as an alternative to the use of GDP per capita alone as a measure of human prosperity. To these ends, it can be suggested that the HDI has achieved overwhelming success. Since 1990, the HDI has included only a limited number of indicators to keep it simple and manageable. This simple HDI algorithm is still being used today and calculated from regularly available data to produce a meaningful value that can be used to compare and rank countries across the world. Nonetheless, it is still prone to criticisms and lacks the means to correctly measure and analyze annual development performance.
Smith (1993) was the first author to suggest and support significant changes in the $\mathrm{HDI}$, while Hopkins (1991), McGillivray (1991), Luchters and Menkoff (2000) and Crafts $(1997,2002)$ have supported the use of the original HDI. On the other hand, there have been many studies in the literature that suggest making radical changes and improvements in the dimensions of the HDI. For example, Srinivasan (1994) and Jordan (2004) have suggested the use of employment or unemployment dimensions in the $\mathrm{HDI}$, while Engineer, King and Roy (2008) calculate the modified indices for OECD countries and compare them with the HDI. Marchante and Ortega (2006) suggested the use of the 100 minus the rate of long-term unemployment together with 6 other dimensions in an augmented version of the Human Development Index (AHDI). Bhattacharya and Mitra (1997) has defined growth in terms of the HDI in a wider sense while analyzing the nature of the transformation of employment in the tertiary sector in relation to economic development.

Paul (1996), Hicks (1997) and, Hirschowitz and Orkin (1997) have worked on the Gini coefficient and the relevance of inequalities. Recently, HDR for 2010 has published an inequality-adjusted HDI. Ogwang (2000) and Fukuda-Parr (2003) have suggested the gender dimension in their studies. Harttgen and Klasen (2010) suggest the use of the household-based HDI.

Furthermore, Doessel ve Gounder (1994) have highlighted the significance of absolute values rather than rankings in dealing with the HDI dimensions, whereas Panigrahi and Sivramkrishna (2002), Morse (2003), Osberg and Sharpe (2003), Cherchye, Ooghe and Van Puyenbroeck (2008) and Seguara and Mayo (2009) are concerned with the problems in $\mathrm{HDI}$ rankings.

Some critics of HDI have stated that it presents an oversimplified view of HD. However, collecting reliable data continues to be the major obstacle in low-income countries (Harkness, 2004). Regarding health and longevity, Harkness notes that mortality data are most likely to be missing in countries where mortality is high. According to another critic, both the resources allocated to economic activities and the levels of inequality that may exist within the economy and between various social classes are not taken into account in the HDI (Foster 2005; UI Haq 1995). In recent years, most critics have taken issue with assigning equal weights to each of the respective indicators of the index (Mahlberg and Obersteiner 2001; Chowdhury and Squire 2006; Lind 2010); but assigning differing weights has been proven unnecessary 
(Stapleton and Garrod, 2007). The HDI has also been extensively criticized for its lack of desirable statistical properties. Wolff, Chong, and Auffhammer (2009) and Taner et al. (2010) have statistically shown and criticized that the countries have been misclassified by the HDI.

The main critics of the HDI, however, have claimed that it uses very few or the wrong indicators in measuring the development performance of countries. The family of HD indices has been continuously evolving and struggling to overcome the statistical weaknesses of certain indicators. In this study, a new indicator, namely, an unemployment index, is proposed and introduced to the formula of the HDI.

The current $\mathrm{HDI}$ ignores the inequality in the distribution of resources across populations. This oversight together with the inadequate use of human resources might fully concern the UNDP and the addition of new indicators, such as the unemployment rate, to the $\mathrm{HDI}$. The current HDI includes two non-income indicators of people's living conditions and one income indicator. The unemployment problem, however, needs to be considered in the long-term development perspective. Thus, this paper suggests that including an unemployment rate indicator in the calculation of the new version of the $\mathrm{HDI}$ would be a meaningful amendment. This new version of $\mathrm{HDI}$ is named the "Unemployment-adjusted Human Development Index" and denoted as HDI-2.

The HDI is not always parallel with GDP per capita. Some countries that are rich in resources like those exporting oil may have high per capita income levels, but they may reach relatively low ranks in term of the HDI. For example, although countries like Oman and Saudi Arabia have considerably high per capita income levels approaching US\$23,000 in 2007, they only managed to attain 56th and 59th HDI rankings among all nations, respectively (UNDP 2009). This is partly due to the fact that existing wealth is unequally distributed and/or other aspects of development have not been appropriately factored in HDI calculations. Countries with high GDP per capita should be penalized in their HDI rankings if they are accompanied by high unemployment rates. Therefore, in order to highlight such deficiencies, it would be beneficial to include further indicators in the calculation of the HDI. The unemployment rate emerges as a good indicator for this purpose.

In today's world, employment can be recognized as a fundamental human right. It brings personal economic freedom. Providing and implementing strategies for meaningful and productive work for youth is one of the main targets of the Millennium development goals. Thus, the capacity to develop and meet the job needs of its citizens must be the major goals of every nation in the coming decades. Employment can be further considered a physical need. It constitutes the essential basis for peace, food security and HD. In this context, securing full employment level can be considered one of the primary objectives of every nation. Moreover, rising employment levels is also beneficial in fostering economic growth and achieving sustainable development.

Furthermore, unemployment is of growing concern because populations have expanded in recent decades at a faster rate than job creation, and because a larger percentage of the population, principally women, seek employment now more than at any time in the past. Economies with high levels of unemployment cannot achieve lasting and sustainable development. To put it differently, economies functioning with a full employment level, and thus, high levels of production, show radical improvements in terms of HD.

Human mobility is one of the major factors influencing employment changes in societies. Thus, migration, both within and beyond borders, has become an increasingly prominent theme in domestic and international debates, and was the topic of the HDR in 2009. While immigration pressures are increasing and have become the major concern in most OECD countries, an increase in the share of immigrants in the labor force is estimated to raise temporarily natives' unemployment over a period of approximately five to ten years (Jean and Jimenez 2007). Changes in the proportion of immigrants in the labor force may have a distributive impact on natives' wages, and a temporary impact on unemployment (Jean et al. 2007).

The unemployment rate is defined as the percentage of the labor force (the employed and unemployed population) aged 15 years and older who are not in paid employment, not self-employed, and who are available for work and have taken specific steps to seek paid employment or self-employment (HDR 2010). It is a measure of the risk that a person will not have a job even if he/she wants to work. Since unemployment negatively affects $H D$, the inverse of the unemployment rate (that is, 1 - unemployment) is the preferred standard in this research.

Although it has not been currently included in the sub-indices of the HDI, the unemployment rate is an indicator of social inclusion and quality-of-life through 
efficient use of human resources. It impacts on well-being far more than loss of income (Clark and Oswald 1994). Unemployment precipitates declines in personal wellbeing, like health deterioration in self-esteem, often leading to suicide, and an increased propensity to engage in illegal activities (Machin and Manning 1998). It also displays considerable variation across countries. These are the rationales for inclusion of an unemployment measure in the proposed $\mathrm{HDI}-2$.

\section{Method}

Formerly, the HDI had been based on three subindices and four indicators: longevity index (LEI), as measured by life expectancy at birth; educational attainment index, as measured by a combination of adult literacy (two-thirds weight) and combined (i.e. primary, secondary and tertiary) enrolment (one-third weight) ratios (El); and standard of living, as measured by real GDP index (Purchasing Power Parity in US\$). To calibrate the dimensions, UNDP has assigned minimum and maximum values (goalposts) for each underlying sub-index. Performance in each sub-index is then calculated and expressed as a value between $0-1$. In the UNDP's approach, these sub-indices are assigned (equal) weights as suggested by Chowdhury and Squire (2006), Stapleton and Garrod (2007) and Nguefack-Tsague, Klasen and Zucchini (2010) as given as below:

$$
\mathrm{HDI}=(\mathrm{LEI}+\mathrm{El}+\mathrm{GDPI}) / 3
$$

However, in our approach, the four indices in the
$\mathrm{HDI}-2$ represent a different set of indicators for assessing the aggregate level of HD with equal weights in the following way:

$$
\mathrm{HDI}-2=(3 * \mathrm{HDI}+\mathrm{RUI}) / 4
$$

where RUI is the new included index, i.e. reversed unemployment index. The HDI-2 calculated likewise as a simple average of the sub-indices via basic algebra for each OECD country as shown in Table 1 . These four subindices address conceptually different aspects of HD, which although correlated do not predetermine one another.

The equal weights allow easy comparison over time and across countries. The assessment of change in HDI-2 over the years (1998-2010) for all OECD countries is tabulated in Table 1. From HDI-2 values, comparisons of achievements between countries at a given year or for a particular country for different periods can also be made.

The data have shown that total unemployment rate and HDI-2 are inversely correlated. Therefore, employment rate is preferred instead. Performance in employment is expressed as a value between 0 and 1 . The following general formula is constructed by scaling directly from the total unemployment rate as (\%) of labor force:

$$
\begin{gathered}
\mathrm{RUI}=1-[(20-\text { Actual Unemployment Rate }) /(20- \\
\text { Minimum })]
\end{gathered}
$$

\begin{tabular}{|c|c|c|c|c|c|}
\hline DIMEIISIOIIS & $\begin{array}{l}\text { Long and healthy } \\
\text { life }\end{array}$ & & dge & $\begin{array}{l}\text { Decent standard of } \\
\text { living }\end{array}$ & $\begin{array}{l}\text { Efficient use of } \\
\text { human resour ces }\end{array}$ \\
\hline IIIDICATORS & $\begin{array}{c}\text { Life expectancy at } \\
\text { birth }\end{array}$ & $\begin{array}{l}\text { Adult } \\
\text { Literacy } \\
\text { Rate }\end{array}$ & $\begin{array}{l}\text { Combined } \\
\text { Enrolment } \\
\text { Ratio }\end{array}$ & $\begin{array}{l}\text { Real GDP per capita } \\
\text { (PPP in US\$) }\end{array}$ & $\begin{array}{c}\text { Total Unemployment } \\
\text { Rate } \\
\text { (\% of labour force) }\end{array}$ \\
\hline $\begin{array}{l}\text { DIMEIISIOI } \\
\text { IIDICES| }\end{array}$ & Longevity index & Educatione & inment index & GDP index & Unemployment index \\
\hline
\end{tabular}

It should be noted that this formula reduces to (maxvalue)/max when min is set to 0.01 due to the concept of

Figure 1: Unemployment-adjusted Human Development Index (HDI-2) 


\begin{tabular}{|c|c|c|c|c|c|c|c|c|c|c|}
\hline & 1998 & 1999 & 2000 & 2001 & 2002 & 2003 & $2004 / 5$ & $2005 / 6$ & 2007 & 2010 \\
\hline Canada & 0.846 & 0.855 & 0.870 & 0.863 & 0.863 & 0.868 & 0.878 & 0.892 & 0.900 & 0.880 \\
\hline Norway & 0.909 & 0.913 & 0.913 & 0.916 & 0.920 & 0.930 & 0.915 & 0.932 & 0.947 & 0.921 \\
\hline United States & 0.889 & 0.898 & 0.905 & 0.890 & 0.883 & 0.883 & 0.899 & 0.906 & 0.910 & 0.854 \\
\hline Australia & 0.845 & 0.863 & 0.876 & 0.869 & 0.879 & 0.890 & 0.901 & 0.910 & 0.923 & 0.904 \\
\hline Iceland & 0.911 & 0.926 & 0.935 & 0.926 & 0.914 & 0.911 & 0.939 & 0.939 & 0.948 & 0.881 \\
\hline Sweden & 0.843 & 0.880 & 0.896 & 0.905 & 0.910 & 0.899 & 0.893 & 0.879 & 0.896 & 0.836 \\
\hline Belgium & 0.833 & 0.838 & 0.868 & 0.868 & 0.866 & 0.859 & 0.855 & 0.857 & 0.871 & 0.813 \\
\hline Netherlands & 0.893 & 0.908 & 0.920 & 0.930 & 0.929 & 0.906 & 0.883 & 0.916 & 0.933 & 0.883 \\
\hline Japan & 0.891 & 0.886 & 0.889 & 0.888 & 0.885 & 0.891 & 0.905 & 0.914 & 0.922 & 0.862 \\
\hline United Kingdom & 0.859 & 0.865 & 0.876 & 0.884 & 0.885 & 0.893 & 0.895 & 0.894 & 0.894 & 0.816 \\
\hline Finland & 0.795 & 0.815 & 0.825 & 0.833 & 0.836 & 0.841 & 0.850 & 0.868 & 0.883 & 0.824 \\
\hline France & 0.791 & 0.804 & 0.826 & 0.834 & 0.835 & 0.834 & 0.833 & 0.846 & 0.867 & 0.811 \\
\hline Switzerland & 0.885 & 0.911 & 0.920 & 0.924 & 0.911 & 0.913 & 0.911 & 0.916 & 0.925 & 0.867 \\
\hline Denmark & 0.871 & 0.875 & 0.884 & 0.896 & 0.894 & 0.885 & 0.894 & 0.913 & 0.918 & 0.858 \\
\hline Germany & 0.815 & 0.836 & 0.849 & 0.849 & 0.844 & 0.836 & 0.834 & 0.846 & 0.856 & 0.871 \\
\hline Austria & 0.874 & 0.875 & 0.886 & 0.886 & 0.884 & 0.881 & 0.883 & 0.901 & 0.912 & 0.841 \\
\hline Luxembourg & 0.895 & 0.906 & 0.910 & 0.913 & 0.913 & 0.913 & 0.900 & 0.898 & 0.918 & 0.841 \\
\hline Ireland & 0.833 & 0.868 & 0.889 & 0.896 & 0.895 & 0.903 & 0.914 & 0.914 & 0.917 & 0.853 \\
\hline Italy & 0.775 & 0.789 & 0.801 & 0.815 & 0.824 & 0.843 & 0.859 & 0.871 & 0.886 & 0.808 \\
\hline New Zealand & 0.834 & 0.850 & 0.863 & 0.871 & 0.880 & 0.890 & 0.905 & 0.910 & 0.916 & 0.885 \\
\hline Spain & 0.690 & 0.734 & 0.759 & 0.809 & 0.798 & 0.804 & 0.839 & 0.856 & 0.862 & 0.758 \\
\hline Greece & 0.785 & 0.763 & 0.773 & 0.790 & 0.803 & 0.816 & 0.808 & 0.833 & 0.853 & 0.797 \\
\hline Portugal & 0.836 & 0.849 & 0.860 & 0.871 & 0.859 & 0.849 & 0.834 & 0.827 & 0.831 & 0.753 \\
\hline Korea Rep. & 0.801 & 0.826 & 0.859 & 0.864 & 0.879 & 0.885 & 0.888 & 0.897 & 0.913 & 0.872 \\
\hline Czech Rep. & 0.801 & 0.773 & 0.774 & 0.790 & 0.809 & 0.808 & 0.815 & 0.829 & 0.861 & 0.831 \\
\hline Slovakia & 0.673 & $\mathrm{n} / \mathrm{a}$ & 0.640 & 0.634 & 0.650 & 0.669 & 0.688 & 0.730 & 0.771 & 0.747 \\
\hline Hungary & 0.763 & 0.784 & 0.794 & 0.803 & 0.814 & 0.824 & 0.814 & 0.812 & 0.817 & 0.821 \\
\hline Poland & 0.728 & 0.696 & 0.674 & 0.653 & 0.639 & 0.648 & 0.675 & 0.730 & 0.790 & 0.760 \\
\hline Mexico & 0.803 & 0.825 & 0.818 & 0.819 & 0.819 & 0.826 & 0.823 & 0.832 & 0.844 & 0.764 \\
\hline Turkey & 0.715 & 0.709 & 0.728 & 0.694 & 0.684 & 0.684 & 0.693 & 0.708 & 0.745 & 0.641 \\
\hline
\end{tabular}

Source: Authors' own calculations using HDR (2000-2010) data

Table 1: HDI-2 values (1998-2010)

structural unemployment (Salop 1979; Richardson et al. 2000). The choice of goalposts is the same over the years. That is, maximum and minimum goalposts are taken as $20 \%$ and $0.01 \%$, respectively. The maximum and mimimum unemployment rates between 1998 and 2010 have been recorded in Portugal in 2004 and in Iceland in 2002 as $19.9 \%$ and $1.4 \%$, respectively.

Although all countries reported in the HDI report are not included, the minimum and maximum unemployment values in this formula have been determined by considering the whole set of countries included in the HDI. This index transformation is used in many indices of social and economic well-being. Increases in the value correspond to decreases in the unemployment value. The range of values is between 0 and 1 , and unlikely to change much from year to year for any country regardless of any improvements. The lower values correspond to higher levels of unemployment and vice versa ${ }^{2}$.

As shown in Figure 1, in addition to the three essential choices of leading a long and healthy life, acquiring knowledge, having access to resources needed for a decent standard of living and efficient use of human resources are included in the measure of $\mathrm{HDI}-2$. This is meant to capture the ability of a nation to utilize the efficient use of human resources.

\section{Data}

The HDI time series are taken from HDRs from different years, i.e. 2000-2010. Table 1 and Table 9 list all the values for HDI-2 and HDI for 1998-2010, respectively.

\footnotetext{
${ }^{2}$ For the values of the unemployment index for the whole analysis period, see Table 8 in the Appendix.
} 


\begin{tabular}{|c|c|c|c|c|c|c|c|c|c|c|}
\hline & 1998 & 1999 & 2000 & 2001 & 2002 & 2003 & $2004 / 5$ & $2005 / 6$ & 2007 & 2010 \\
\hline $\mathbf{T}$ & -7.428 & $-7,149$ & -6.116 & -6.430 & -7.045 & 8.165 & -9.243 & 10.699 & 11,973 & $-5,946$ \\
\hline $\begin{array}{l}\text { t-significance (2- } \\
\text { tailed) }\end{array}$ & 0.000 & 0.000 & 0.000 & 0.000 & 0.000 & 0.000 & 0.000 & 0.000 & 0,000 & 0,000 \\
\hline Pearson Correlation & 0.710 & 0.715 & 0.749 & 0.785 & 0.771 & 0.814 & 0.808 & 0.809 & 0,864 & 0,553 \\
\hline $\begin{array}{l}\text { Significance (2- } \\
\text { tailed) }\end{array}$ & 0.000 & 0.000 & 0.000 & 0.000 & 0.000 & 0.000 & 0.000 & 0.000 & 0,000 & 0,000 \\
\hline
\end{tabular}

Table 2: Paired t-test and Pearson Correlation

\begin{tabular}{|c|c|c|c|c|c|c|c|c|c|c|}
\hline & 1998 & 1999 & 2000 & 2001 & 2002 & 2003 & $2004 / 5$ & $2005 / 6$ & 2007 & 2010 \\
\hline Canada & 1 & 3 & 3 & 6 & 4 & 4 & 6 & 4 & 4 & 7 \\
\hline Norway & 2 & 1 & 1 & 1 & 1 & 1 & 1 & 1 & 1 & 1 \\
\hline United States & 3 & 6 & 4 & 8 & 8 & 10 & 8 & 12 & 13 & 4 \\
\hline Australia & 4 & 2 & 4 & 4 & 3 & 3 & 3 & 3 & 2 & 2 \\
\hline Iceland & 5 & 7 & 7 & 2 & 7 & 2 & 2 & 1 & 3 & 15 \\
\hline Sweden & 6 & 3 & 2 & 3 & 2 & 4 & 5 & 6 & 7 & 8 \\
\hline Belgium & 7 & 5 & 4 & 8 & 5 & 9 & 12 & 17 & 17 & 16 \\
\hline Netherlands & 8 & 8 & 8 & 5 & 5 & 11 & 10 & 9 & 6 & 6 \\
\hline Japan & 9 & 9 & 9 & 9 & 9 & 11 & 7 & 8 & 10 & 10 \\
\hline United Kingdom & 10 & 14 & 11 & 12 & 10 & 15 & 17 & 16 & 20 & 23 \\
\hline Finland & 11 & 10 & 10 & 12 & 13 & 13 & 11 & 10 & 12 & 14 \\
\hline France & 12 & 12 & 11 & 17 & 18 & 16 & 16 & 10 & 8 & 13 \\
\hline Switzerland & 13 & 11 & 11 & 10 & 10 & 7 & 9 & 7 & 9 & 12 \\
\hline Denmark & 14 & 15 & 15 & 11 & 16 & 13 & 15 & 13 & 16 & 17 \\
\hline Germany & 15 & 15 & 16 & 18 & 19 & 20 & 21 & 21 & 21 & 8 \\
\hline Austria & 16 & 15 & 14 & 16 & 14 & 17 & 14 & 15 & 14 & 22 \\
\hline Luxembourg & 17 & 12 & 16 & 14 & 15 & 5 & 13 & 18 & 11 & 21 \\
\hline Ireland & 18 & 18 & 16 & 14 & 10 & 8 & 4 & 5 & 5 & 5 \\
\hline Italy & 19 & 20 & 20 & 21 & 21 & 18 & 17 & 20 & 18 & 20 \\
\hline New Zealand & 20 & 19 & 19 & 20 & 18 & 19 & 20 & 19 & 19 & 3 \\
\hline Spain & 21 & 21 & 20 & 19 & 20 & 21 & 19 & 13 & 15 & 18 \\
\hline Greece & 22 & 22 & 22 & 23 & 22 & 22 & 22 & 22 & 22 & 19 \\
\hline Portugal & 23 & 24 & 24 & 22 & 23 & 23 & 24 & 24 & 24 & 27 \\
\hline Korea Rep. & 24 & 23 & 23 & 24 & 24 & 24 & 23 & 23 & 23 & 11 \\
\hline Czech Rep. & 25 & 25 & 24 & 25 & 25 & 25 & 25 & 25 & 25 & 24 \\
\hline Slovakia & 26 & $\mathrm{n} / \mathrm{a}$ & 27 & 28 & 28 & 28 & 28 & 28 & 27 & 25 \\
\hline Hungary & 27 & 26 & 26 & 27 & 27 & 26 & 26 & 26 & 28 & 26 \\
\hline Poland & 28 & 27 & 28 & 26 & 26 & 27 & 27 & 27 & 26 & 27 \\
\hline Mexico & 29 & 28 & 29 & 29 & 29 & 29 & 29 & 29 & 29 & 29 \\
\hline Turkey & 30 & 29 & 30 & 30 & 30 & 30 & 30 & 30 & 30 & 30 \\
\hline
\end{tabular}

Source: Human Development Reports (2000 - 2010)

Table 3: Rankings of OECD countries in terms of the HDI

In all tables, the countries are listed in the same rank order as HDI-1998.

For all years and countries, $\mathrm{HDI}-2$ values are always lower than HDI values except for Iceland, Hungary and Mexico in 2010. The improvements in HDI values over the years seem to originate from the changes in GDPI since the values of $\mathrm{LEl}$ and $\mathrm{El}$ remained almost the same. On the other hand, many OECD countries represent a significant improvement in HDI-2 over the years. This is partly attributable to the inclusion of the unemployment index in the calculation of the HDI.
Table 3 and Table 4 list all the ranks for the HDI and $\mathrm{HDI}-2$ for 1998-2010, respectively. According to HDI-2, Norway has always been ranked among the top 4 countries. Only the Republic of Korea has experienced a continuous rise in $\mathrm{HDI}-2$ rankings throughout the analysis period due to the structure of its economy. It is observed that the Netherlands experienced a drastic fall in rank in 2004/5 after being ranked as the 1st in 2001 and 2002. This sharp decline is due to the variations in its unemployment rate. On the other hand, significant 


\begin{tabular}{|c|c|c|c|c|c|c|c|c|c|c|}
\hline & 1998 & 1999 & 2000 & 2001 & 2002 & 2003 & $2004 / 5$ & $2005 / 6$ & 2007 & 2010 \\
\hline Canada & 11 & 14 & 14 & 18 & 17 & 16 & 16 & 15 & 14 & 3 \\
\hline Norway & 2 & 2 & 4 & 4 & 2 & 1 & 2 & 2 & 2 & 1 \\
\hline United States & 6 & 6 & 6 & 9 & 12 & 14 & 9 & 10 & 13 & 15 \\
\hline Australia & 12 & 13 & 12 & 15 & 14 & 10 & 7 & 8 & 5 & 11 \\
\hline Iceland & 1 & 1 & 1 & 2 & 3 & 4 & 1 & 1 & 1 & 6 \\
\hline Sweden & 13 & 8 & 7 & 6 & 6 & 7 & 12 & 16 & 15 & 19 \\
\hline Belgium & 16 & 17 & 15 & 16 & 16 & 17 & 18 & 19 & 19 & 22 \\
\hline Netherlands & 4 & 4 & 2 & 1 & 1 & 5 & 14 & 4 & 3 & 2 \\
\hline Japan & 5 & 7 & 8 & 10 & 9 & 9 & 5 & 6 & 6 & 12 \\
\hline United Kingdom & 10 & 12 & 12 & 12 & 9 & 8 & 10 & 14 & 16 & 17 \\
\hline Finland & 22 & 21 & 21 & 21 & 20 & 20 & 19 & 18 & 18 & 20 \\
\hline France & 23 & 22 & 20 & 20 & 21 & 22 & 23 & 21 & 20 & 24 \\
\hline Switzerland & 7 & 3 & 2 & 3 & 5 & 2 & 4 & 3 & 4 & 5 \\
\hline Denmark & 9 & 9 & 11 & 7 & 8 & 12 & 11 & 7 & 7 & 7 \\
\hline Germany & 18 & 18 & 19 & 19 & 19 & 21 & 20 & 22 & 23 & 10 \\
\hline Austria & 8 & 9 & 10 & 11 & 11 & 15 & 14 & 11 & 12 & 9 \\
\hline Luxembourg & 3 & 5 & 5 & 5 & 4 & 2 & 8 & 12 & 7 & 4 \\
\hline Ireland & 16 & 11 & 8 & 7 & 7 & 6 & 3 & 5 & 9 & 18 \\
\hline Italy & 25 & 23 & 23 & 23 & 22 & 19 & 17 & 17 & 17 & 23 \\
\hline New Zealand & 15 & 15 & 16 & 13 & 13 & 10 & 5 & 9 & 10 & 13 \\
\hline Spain & 29 & 27 & 27 & 24 & 27 & 27 & 20 & 20 & 21 & 29 \\
\hline Greece & 24 & 26 & 26 & 26 & 26 & 25 & 27 & 23 & 24 & 25 \\
\hline Portugal & 14 & 16 & 17 & 13 & 18 & 18 & 20 & 26 & 26 & 26 \\
\hline Korea Rep. & 20 & 19 & 18 & 17 & 14 & 12 & 13 & 13 & 11 & 8 \\
\hline Czech Rep. & 20 & 25 & 25 & 26 & 25 & 26 & 25 & 25 & 22 & 16 \\
\hline Slovakia & 30 & $\mathrm{n} / \mathrm{a}$ & 30 & 30 & 29 & 29 & 29 & 29 & 29 & 28 \\
\hline Hungary & 26 & 24 & 24 & 25 & 24 & 24 & 26 & 27 & 27 & 14 \\
\hline Poland & 27 & 29 & 29 & 29 & 30 & 30 & 30 & 28 & 28 & 27 \\
\hline Mexico & 19 & 20 & 22 & 22 & 23 & 23 & 24 & 24 & 25 & 21 \\
\hline Turkey & 28 & 28 & 28 & 28 & 28 & 28 & 28 & 30 & 30 & 30 \\
\hline
\end{tabular}

Source: Authors' own calculations using HDR (2000-2010) data

Table 4: Ranks of OECD countries as for HDI-2

advances in the rankings of Australia, Ireland, Italy, New Zealand, and Spain are observed.

The stability of the rankings has increased. The rankings of some developed countries such as Belgium, France and Greece, and developing countries such as Poland, Slovakia and Turkey, remained almost the same. These three developing countries often act like outliers in the sample.

Most OECD countries experienced a fall in their employment in 2001 and 2002 while their GDPIs have increased. This has resulted in falls in their HDI-2 for these years (See Table 1 and Table 5). This trend can be further considered a signal of "jobless growth" for the same OECD countries.

\section{Empirical Analysis}

All LEI, El, GDPI, RUI and HDI values are obtained from HDRs. Then, for each year, the HDI values are compared with the values of $\mathrm{HDI}-2$ by means of a paired t-test. The results indicate that the difference between the two indices are statistically significant.

To analyze the impact of the modification between the $\mathrm{HDI}$ and HDI-2, a Pearson Correlation is employed. The results show that there is high rank of correlation between $\mathrm{HDI}$ rankings and $\mathrm{HDI}-2$ rankings as tabulated in Table 2. The results show that adjusting for unemployment results in major changes in the rankings of countries. The results for all years show that the difference between the rankings of two indices are statistically significant. The behavior of HDI 2010 against HDI-2 2010 is displayed in Figure 2. In addition, the 


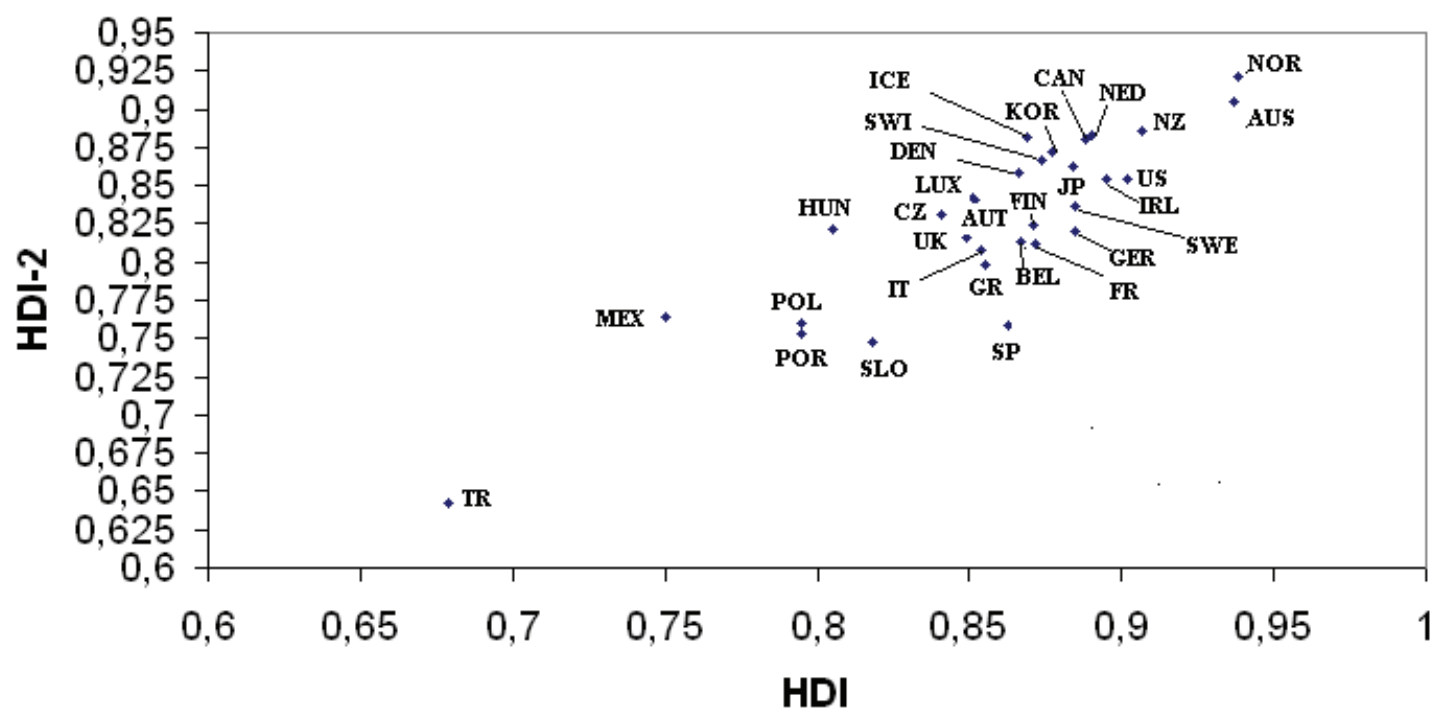

Figure 2: HDI 2010 versus HDI-2 2010 for OECD countries

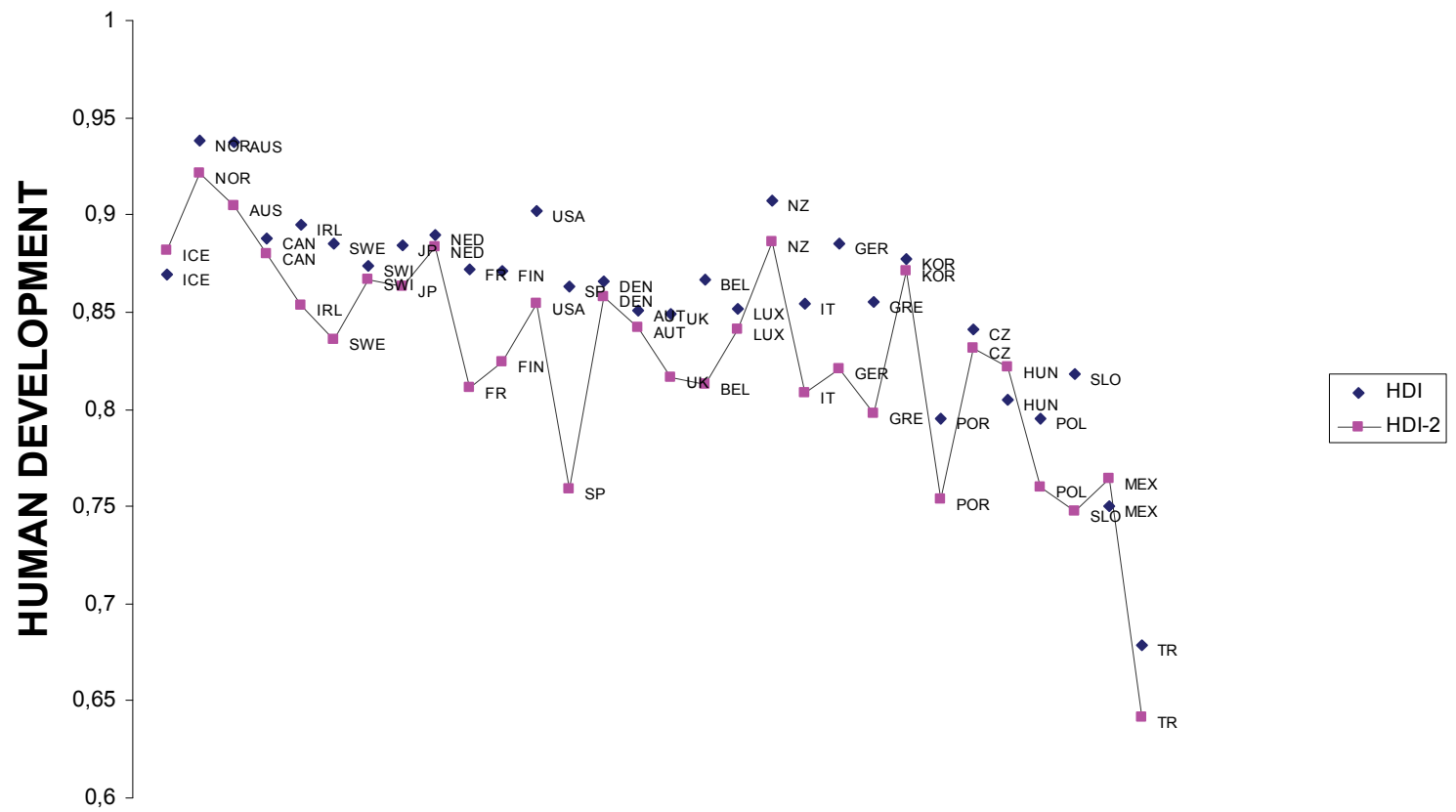

OECD COUNTRIES

Figure 3: The Impact of the Unemployment rate on HDI for 30 OECD countries

impact of the unemployment rate on HDI for 30 OECD countries is displayed in Figure 3.

Comparing the rankings of nations given by the HDI and $\mathrm{HDI}-2$ gives one a basis for assessing whether the added unemployment information matters or not. Table 5 shows how much each country's rank order changed from the UNDP's HDI ranking. As shown in Table 5, inclusion of the unemployment index in HDI calculations has resulted in crucial increases in the rankings of the Republic of Korea, Denmark, Luxembourg and Switzerland for all years. These OECD countries have made evident and concrete amelioration in the context of HD. The inclusion of unemployment rate had no particular effect on the ranks of Turkey, Slovakia and Poland. 


\begin{tabular}{|c|c|c|c|c|c|c|c|c|c|c|}
\hline & 1998 & 1999 & 2000 & 2001 & 2002 & 2003 & $2004 / 5$ & $2005 / 6$ & 2007 & 2010 \\
\hline Canada & 10 & 11 & 11 & 12 & 13 & 12 & 10 & 11 & 10 & -4 \\
\hline Norway & 0 & 1 & 3 & 3 & 1 & 0 & 1 & 1 & 1 & 0 \\
\hline United States & 3 & 0 & 2 & 1 & 4 & 4 & 1 & -2 & 0 & 11 \\
\hline Australia & 8 & 11 & 8 & 11 & 11 & 7 & 4 & 5 & 3 & 9 \\
\hline Iceland & -4 & -6 & -6 & 0 & -4 & 2 & -1 & 0 & -2 & -9 \\
\hline Sweden & 7 & 5 & 5 & 3 & 4 & 3 & 7 & 10 & 8 & 11 \\
\hline Belgium & 9 & 12 & 11 & 8 & 11 & 8 & 6 & 2 & 2 & 6 \\
\hline Netherlands & -4 & -4 & -6 & -4 & -4 & -6 & 4 & -5 & -3 & -4 \\
\hline Japan & -4 & -2 & -1 & 1 & 0 & -2 & -2 & -2 & -4 & 2 \\
\hline United Kingdom & 0 & -2 & 1 & 0 & -1 & -7 & -7 & -2 & -4 & -6 \\
\hline Finland & 11 & 11 & 11 & 9 & 7 & 7 & 8 & 8 & 6 & 6 \\
\hline France & 11 & 10 & 9 & 3 & 3 & 6 & 7 & 11 & 12 & 11 \\
\hline Switzerland & -6 & -8 & -9 & -7 & -5 & -5 & -5 & -4 & -5 & -7 \\
\hline Denmark & -5 & -6 & -4 & -4 & -8 & -1 & -4 & -6 & -9 & -10 \\
\hline Germany & 3 & 3 & 3 & 1 & 0 & 1 & -1 & 1 & 2 & 2 \\
\hline Austria & -8 & -6 & -4 & -5 & -3 & -2 & 0 & -4 & -2 & -13 \\
\hline Luxembourg & -14 & -7 & -11 & -9 & -11 & -3 & -5 & -6 & -4 & -17 \\
\hline Ireland & -2 & -7 & -8 & -7 & -3 & -2 & -1 & 0 & 4 & 13 \\
\hline Italy & 6 & 3 & 3 & 2 & 1 & 1 & 0 & -3 & -1 & 3 \\
\hline New Zealand & -5 & -4 & -3 & -7 & -5 & -9 & -15 & -10 & -9 & 10 \\
\hline Spain & 8 & 6 & 7 & 5 & 7 & 6 & 1 & 7 & 6 & 11 \\
\hline Greece & 2 & 4 & 4 & 3 & 4 & 3 & 5 & 1 & 2 & 6 \\
\hline Portugal & -9 & -8 & -7 & -9 & -5 & -5 & -4 & 2 & 2 & -1 \\
\hline Korea Rep. & -4 & -4 & -5 & -7 & -10 & -12 & -10 & -10 & -12 & -3 \\
\hline Czech Rep. & -5 & 0 & 1 & 1 & 0 & 1 & 0 & 0 & -3 & -8 \\
\hline Slovakia & 4 & $\mathrm{n} / \mathrm{a}$ & 3 & 2 & 1 & 1 & 1 & 1 & 2 & 3 \\
\hline Hungary & -1 & -2 & -2 & -2 & -3 & -2 & 0 & 1 & -1 & -12 \\
\hline Poland & -1 & 2 & 1 & 3 & 4 & 3 & 3 & 1 & 2 & 0 \\
\hline Mexico & -10 & -8 & -7 & -7 & -6 & -6 & -5 & -5 & -4 & -8 \\
\hline Turkey & -2 & -1 & -2 & -2 & -2 & -2 & -2 & 0 & 0 & 0 \\
\hline
\end{tabular}

Source: Authors' own calculations using HDR (2000-2010) data

Table 5: Differences in HDI rankings (HDI-2 rank less HDI rank)

Additionally, unemployment negatively affected the $\mathrm{HDI}$ values of some OECD countries, especially Canada, France, Sweden, Finland and Spain. The drops in the rankings of these countries were crucial. These countries are among those to experience net inflows of migrants since their GDP per capita has had an increasing trend (HDR 2009). Therefore, they should address unemployment, control immigration, make adjustments and implement new policies regarding immigrants' integration into the host country's labor market. As these adjustments may depend on country-specific factors, the influence of immigrants on the wage setting mechanism needs to be studied to lead to the creation of economic opportunities for the natives.

The global economic crisis has negatively impacted on the GDP per capita and unemployment indices of the developed economies in 2010. Both the HDI and HDI-2 have decreased for all OECD countries except for Hungary, which shows a slight increase in its HDI-2.
In our sample of 30 OECD countries, Spain has the highest unemployment rate at $11.3 \%$ in 2010 , while the Netherlands shows the lowest, $2.8 \%$ for the same period. The Unemployment Index has decreased for Iceland, the United States, the United Kingdom, Spain, Italy, Luxembourg and New Zealand in 2010, whereas it has increased by $34,92 \%$ in Hungary that year.

Using our approach, Iceland, Luxembourg and France lost (12), (10) and (5) HDI places in their rankings due to the global crisis, whereas the ranks of New Zealand, Germany, the Republic of Korea and the United States have been increased by (16), (13), (12) and (9), respectively. The rankings of Norway, Australia, the Netherlands, Mexico and Turkey remained unaffected among the OECD countries with respect to the previous year. The GDP per capita of developing OECD countries such as Turkey has been badly affected in 2010 after a prosperous year in 2007 (See Table 3). 


\begin{tabular}{|c|c|c|}
\hline HDI-2 less HDI & Number of Countries & Countries \\
\hline-17 & 1 & Luxembourg \\
\hline-13 & 1 & Hungary \\
\hline-12 & 1 & Denmark \\
\hline-10 & 1 & Iceland \\
\hline-9 & 1 & Mexico, Czech Republic \\
\hline-8 & 2 & Switzerland \\
\hline-7 & 1 & Canited Kingdom \\
\hline-6 & 1 & Republic of Korea \\
\hline-4 & 2 & Portugal \\
\hline-3 & 1 & Norway, Poland, Turkey \\
\hline-1 & 1 & Japan, Germany \\
\hline 0 & 3 & Italy, Slovakia \\
\hline 2 & 2 & Finland, Belgium, Greece \\
\hline 3 & 2 & Australia \\
\hline 6 & 3 & New Zealand \\
\hline 9 & 1 & Sweden, United States, Spain \\
\hline 10 & 1 & Ireland \\
\hline 11 & 3 & 1 \\
\hline
\end{tabular}

Table 6: Table of ranking difference, i.e. HDI-2 less HDI (HDR 2010)

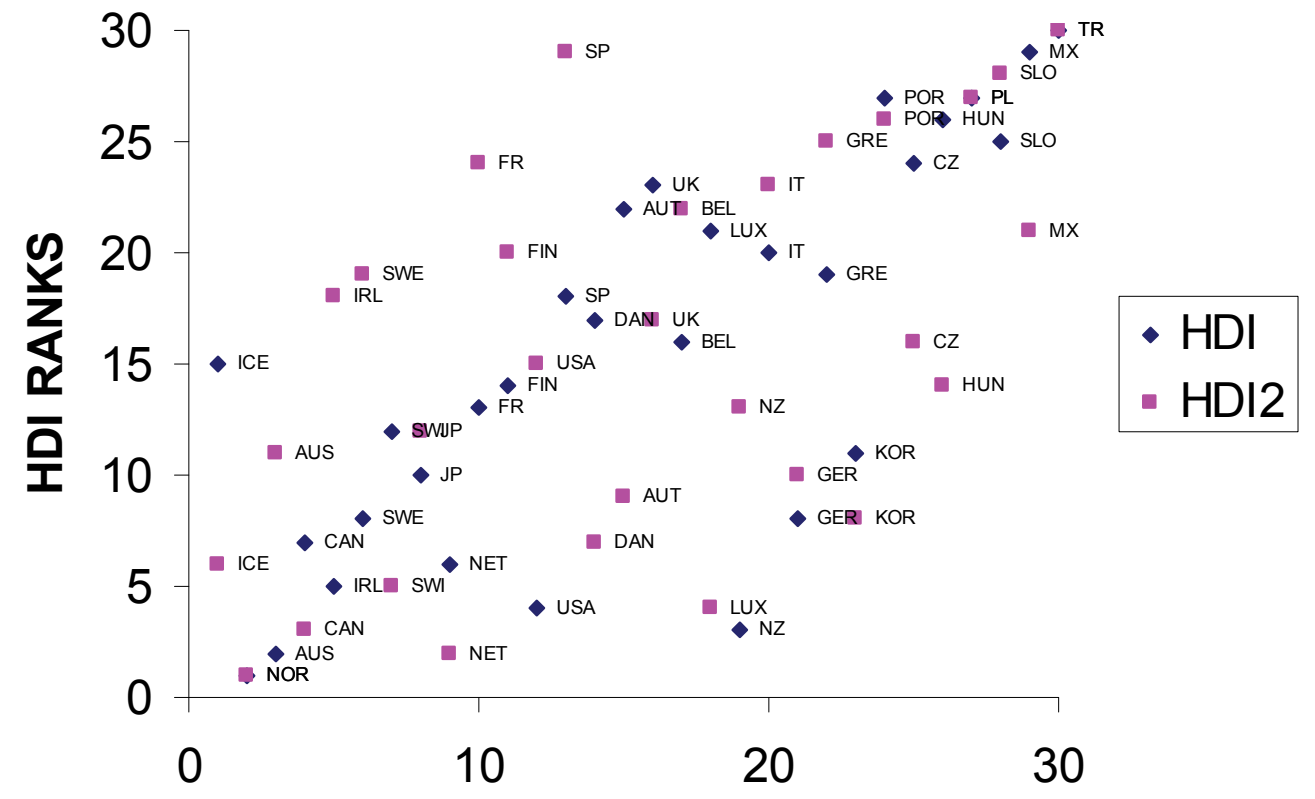

\section{HDI-2 RANKS}

Figure 4: Distribution of HDI ranks in 2010 and HDI-2 ranks in 2010 (Data taken from HDR 2010)

Unlike the rankings announced by the UNDP, the ranking of the United States dropped by (2) in 2010 according to our proposed index. This is logical when the severeness of the crisis in United States is considered. Our analysis shows that the HDI has underestimated the effects of the global crisis in Ireland, Greece, New Zealand, Finland, Australia, Sweden, France, Spain and Belgium.
Our analysis also further indicates that the economies of Switzerland, Iceland, Hungary, Luxembourg, Denmark, Austria, Canada and the Netherlands have not been hit by the global crisis as severely as has been alleged.

For 2010, a table for ranking changes between the HDI and our proposed HDI-2 is provided (See Table 6). While there is no change in ranking in 3 countries; 14 countries 
show a positive change in ranking (implying improved rankings under $\mathrm{HDI}-2$ ) while 13 countries show a negative change in ranking (implying worsening rankings under $\mathrm{HDI}-2$ ). Nineteen countries show a ranking change that is greater than 5 in absolute value. The mode of the absolute value of ranking change is (11). In the top developed countries, the most substantial changes in ranking were Luxembourg (17), Ireland (13), Austria (13) and Hungary (12). In the top developed countries, the most dramatic gains were shown by Luxembourg (17), Austria (13), Hungary (12) and Denmark (10). The maximum drop in ranking was by Ireland (13).

\section{Discussion and Concluding Remarks}

This study can be considered an initial argument for inclusion of the unemployment factor in the HDI. It argues in favor of enriching the HDI, which is based on three indices: for longevity, educational attainment and per capita GDP, with a fourth index for employment.

The great advantage of the HDI is that it covers both developed and developing countries, but a weakness is that it is not particularly useful for developed countries as the value for these countries are often bunched together. In this paper, the proposed index is calculated mostly for developed countries, which reduces its usefulness for tracking human development globally. Yet, the introduction of the employment index component does result in greater differentiation among developed countries.

The proposed index introduces a new understanding of well-being as an alternative or companion to the HDI as a way to measure levels of HD for comparison across both countries and time.

By means of this new method, the number of HDI determinants has slightly increased, but it still remains manageable and easily understood, enabling one to define HD in a more holistic way. It is understood that the process required to attain high and very high development levels is a greater struggle than the current HDI envisaged.

Development, and especially HD, should not solely consist of economic growth. In fact, increasing each indicator's weight from $1 / 3$ to $1 / 4$ diminishes the effect of GDPI in the HDI. Lowering the weighting by including more human and social factors would better fit the HDI's nature. Assuming that "growth is a necessary but not sufficient condition for development," humanitarian aspects of development should be encapsulated in its measurement and assessment.

As educational attainment and longevity indices do not show significant improvements in the short term, the $\mathrm{HDI}$ value may likely change from year to year for any country only by means of the improvements in GDP per capita. Inclusion of unemployment as a dynamic measure that may significantly vary from year to year can bring additional explanatory power to the index.

Unemployment is a relatively more advanced indicator variable to be incorporated in a modified HDI index. Its inclusion provides balance to the index. With improved explanatory power, the proposed version of the HDI gives more information about the development performance of nations. Furthermore, it is a relatively more advanced quantitative instrument to evaluate the HD capacity of countries. The inclusion of an unemployment factor in $\mathrm{HDI}$ substantially altered the overall ranking of nations. Through adding a fourth subindex to the current $\mathrm{HDI}$, namely the unemployment index, the HDI has become more comprehensive with respect to development. The new HDI favors countries attempting to overcome the problem of unemployment. The effect of adding the dimension of unemployment has resulted in more sensible and realistic rankings between OECD countries.

The new HDI-2 values have shown that there is a need to attain better HD performance due to the problem of a global increase in unemployment. Therefore, this problem is reflected in HDI measurements and additional goals for HD are suggested. Without the dimension of unemployment, the current $\mathrm{HDI}$ measures might direct policy makers to emphasize heavily the overall income factors, such as GDP, to increase HD. This is due to the fact that non-income factors approach their limit, especially for highly developed countries. However, the distribution of income among people and the probability and chance of having a job should also be considered in evaluating nations' HD levels.

As shown in Table 1 and Table 9, the HDI-2 values are generally lower than those of the HDI for each year. Moreover, they follow an increasing trend over the years. The year 2001 was exceptional, as the HDI decreased for Japan, France, the United States, Belgium, Luxembourg, Germany, Greece, the Republic of Korea, Portugal, the Czech Republic, Hungary, Poland, Slovakia, Mexico and Turkey. The year 2010 has also been equally exceptional.

This study shows that the strong economies of Switzerland, Japan, South Korea and Denmark have been 
underestimated by the HDI. On the other hand, the HDI has overestimated the economies of Australia, Ireland, Canada, Sweden, Germany and Spain. Including the unemployment factor to the $\mathrm{HDI}$ as a new indicator has made the index broader. The integrity of the HDI is more assured for assessing the development performance of countries. Its concept is more complete and interpretable.

One major limitation of the study is that although the original values and rankings in HDR-2010 are based on 169 countries out of the 192 UN member countries worldwide, in this paper 30 OECD economies are taken as the research sample due to the obstacles in obtaining reliable data and then re-ranked among themselves. It should be further noted that most economies in the sample are at a stage of very high development. Only seven can be considered developing, namely the Czech Republic, the Republic of Korea, Hungary, Slovakia, Mexico, Poland and Turkey. A major potential problem in expanding the unemployment index to developing countries is that the concepts of unemployment are much harder to apply when the informal sector or household activities are very important in the developing world (Hirschowitz and Orkin 1997). In poor counties, with no social safety net, everyone has to do something to survive, so that the vast majority of the working age population is engaged in some sort of gainful activity, no matter how poorly productive. Therefore, future research studies in a similar context should consider such differences between developed and developing countries.

Additionally, the years included in the analyses are from 1998 to 2010. Since the actual values of the HDI are not available after 2007 (or HDR 2009), estimates for the components of the HDI 2010 have been directly adapted from the HDR 2010. However, the year 2009 saw changes in both unemployment and income in both developing and developed countries due to the economic crisis. There would be much greater cyclical variation in HDI values if the data were available for these years.

Future studies may offer new and more advanced approaches for the usage of the HDI in the assessment of development. Similarly, future research agendas may also focus on the computation of the HDI through adding new indicators relevant for $\mathrm{HD}$.

Future studies will hopefully fill in the gap for the lack of data for many countries and permit the development of more comprehensive and reliable calculation of the HDI. Nevertheless, it is believed that the current study provides significant insights for a better understanding of the development process and the implementation of public policies. ㄹ.

\section{References}

Bhattacharya, B.B. and Mitra, A. 1997. "Changing Composition of Employment in the Tertiary Sector: A Cross-Country Analysis," Economic and Political Weekly 32(11): 529-534.

Cherchye, L., Ooghe, E., and Van Puyenbroeck, T. 2008. "Robust human development rankings," Journal of Economic Inequality 6(4): 287321.

Chowdhury, S., and Squire, L. 2006. "Setting Weights for Aggregate Indices: An Application to the Commitment to Development Index and Human Development Index," Journal of Development Studies 42(5): 761771.

Clark, A. E., and Oswald, A. J. 1994. "Unhappiness and unemployment," Economic Journal 104: 648-659.

Crafts, N.F.R. 1997. "The Human Development Index and changes in standards of living: Some historical comparisons," European Review of Economic History 1: 299-322.

Crafts, N. 2002. "The human development index, 1870-1999: Some revised estimates," European Review of Economic History 6: 395-405.

Doessel, D.P., and Gounder, R. 1994. "Theory and measurement of living levels: Some empirical results for the human development index," Journal of International Development 6(4): 415-435.

Engineer, M., King, I., and Roy, N. (2008). "The Human Development Index as a Criterion for Optimal Planning," Working Papers Series, 2008/1041, Melbourne: The University of Melbourne, Department of Economics.

Foster, J., Lopez-Calva, L., and Szekely, M. 2005. "Measuring the Distribution of Human Development: Methodology and an Application to Mexico," Journal of Human Development 6(1): 5-29.

Fukuda-Parr, S. 2003. "The Human Development Paradigm: Operationalizing Sen's Ideas On Capabilities," Feminist Economics 9: 301317.

Harkness, S. (2004), "Social and Political Indicators of Human WellBeing," Research Paper, 2004/33, Helsinki: United Nations University: World Institute for Development Economics Research (WIDER).

Harttgen, K., and Klasen, S. (2010), "A Household-Based Human Development Index," Human Development Research Papers, 2010/22, New York: United Nations Development Programme.

Hicks, D.A. 1997. "The inequality-adjusted Human Development Index: A Constructive Proposal," World Development 25(8): 1283-1298.

Hirschowitz, R. and Orkin, M. 1997. "Inequality in South Africa: Findings from the 1994 October Household Survey," Social Indicators Research 41 (1-3): 119-136.

Hopkins, M. 1991. "Human Development Revisited: A New UNDP Report," World Development 19(10): 1469-1473.

Human Development Reports (1990, 1991, 1994, 1995, 1999, 2000 2001, 2002, 2003, 2004, 2005, 2006, 2007-8, 2009, 2010), United Nations Development Programme, New York: Oxford University Press.

Jean, S., Causa, O., Jimenez, M., and Wanner, I. (2007), "Migration in OECD countries: Labor market impact and integration issues," OECD Economics Department Working Papers, 2007/562, Paris: OECD Economics Department.

Jean, S., and Jimenez, M. (2007), "The Unemployment Impact of Immigration in OECD countries," OECD Economics Department Working Papers, 2007/563, Paris: OECD Economics Department.

Jordan, J.L. (2004), "Constructing a Human Development Index for Georgia's Counties," University of Georgia, Department of Agricultural 
and Applied Economics Faculty Series, 2004/16672, Athens: University of Georgia, Department of Agricultural and Applied Economics.

Khan, H. 1991. "Measure and determinants of socioeconomic development: a critical conspectus," Social Indicators Research 24: 153175.

Lind, N. 2010. "A Calibrated Index of Human Development," Social Indicators Research 98: 301-319.

Lüchters, G., and Menkhoff, L. 2000. "Chaotic Signals from HDI Measurement," Applied Economics Letters 7(4): 267-270.

Machin, S., and Manning, A. (1998), "The Causes and Consequences of Long-Term Unemployment in Europe," Centre for Economic Performance, London School of Economics and Political Science Report, 1998/400, London: London School of Economics and Political Science.

Marchante, A.J., and Ortega, B. 2006. "Quality of Life and Economic Convergence across Spanish Regions, 1980-2001." Regional Studies 40(5): 471-483.

Mazumdar, K. 1999. "Measuring the well-being of developing countries: achievement and improvement indices," Social and Industrial Research 47: 1-60.

McGillivray, M. 1991. "The Human Development Index: Yet Another Redundant Composite Development Indicator?", World Development 19(10): 1461-1468.

Nguefack-Tsague, G., Klasen, S., and Zucchini, W. (2010), "On weighting the components of the Human Development Index: A statistical justification," Courant Research Centre: Poverty, Equity and Growth, Discussion Papers, 2010/37, Goettingen: Courant Research Centre: Poverty, Equity and Growth.

Ogwang, T. 2000. "Inter-country inequality in human development indicators," Applied Economics Letters 7(7): 443-446.

Osberg, L., and Sharpe, A. (2003), "Human Well-being and Economic Well-being: What Values Are Implicit in Current Indices?", Centre for the Study of Living Standards Research Report 2003/04, Ottowa: Centre for the Study of Living Standards.

Panigrahi, R., and Sivramkrishna, S. 2002. "An adjusted Human Development Index: Robust country rankings with respect to the choice of fixed maximum and minimum indicator values." Journal of Human Development 3(2): 301-311.

Paul, S. 1996. "A modified human development index and international comparison." Applied Economics Letters 3(10): 677-682.

Richardson, P., Boone, L. Giorno, C., Meacci, M. Rae, D. and Turner, D. (2000), "The Concept, Policy Use and Measurement of Structural Unemployment: Estimating a Time Varying NAIRU Across 21 OECD Countries," OECD Economics Department Working Papers, 2000/250, Paris: OECD Economics Department.

Salop, S.C. 1979. "A Model of the Natural Rate of Unemployment," The American Economic Review 69(1): 117-125.

Smith, P. 1993. "Measuring human development." Asian Economic Journal 7(1): 89-106.

Smith, R.B. 2009. "Global human development: accounting for its regional disparities," Quality and Quantity 43(1): 1-34.

Srinivasan, T.N. 1994. "Human development: a new paradigm or reinvention of the wheel?" The American Economic Review. 84(2): 238243.

Stapleton, L.M., and Garrod, G.D. 2007. "Keeping things simple: why the Human Development Index should not diverge from its equal weights assumption." An International and Interdisciplinary Journal for Quality-of-Life Measurement 84(2): 179-188.

Taner, M.T., Sezen, B., Alpkan, L., and Aren, S. 2010. Recomputation of UNDP's HDI rankings by Data Envelopment Analysis. VI. International Strategic Management Conference, St.Petersburg, Russia, July.

UI Haq, M. 1995. Reflections on Human Development. New York: Oxford University Press.
Wolff, H., Chong H., and Auffhammer, M. 2009. Human Development Index: Are Developing Countries Misclassified? Agricultural and Applied Economics Association Annual Meeting, Milwaukee, Wisconsin, July. 


\section{Appendix}

\begin{tabular}{|c|c|c|c|c|c|c|c|c|c|c|}
\hline & 1998 & 1999 & 2000 & 2001 & 2002 & 2003 & $2004 / 5$ & $2005 / 6$ & 2007 & 2010 \\
\hline Canada & 0.91 & 0.93 & 0.94 & 0.94 & 0.95 & 0.96 & 0.96 & 0.970 & 0.982 & 0.844 \\
\hline Norway & 0.93 & 0.94 & 0.95 & 0.95 & 0.99 & 0.99 & 0.99 & 1.000 & 1.000 & 0.906 \\
\hline United States & 0.95 & 0.96 & 0.97 & 0.97 & 0.98 & 0.99 & 1.00 & 1.000 & 1.000 & 0.872 \\
\hline Australia & 0.90 & 0.92 & 0.93 & 0.92 & 0.94 & 0.95 & 0.95 & 0.962 & 0.977 & 0.849 \\
\hline Iceland & 0.92 & 0.94 & 0.95 & 0.95 & 0.95 & 0.96 & 0.98 & 0.985 & 0.981 & 0.820 \\
\hline Sweden & 0.89 & 0.90 & 0.92 & 0.92 & 0.93 & 0.93 & 0.95 & 0.965 & 0.986 & 0.832 \\
\hline Belgium & 0.91 & 0.92 & 0.94 & 0.92 & 0.94 & 0.94 & 0.96 & 0.963 & 0.977 & 0.826 \\
\hline Netherlands & 0.90 & 0.92 & 0.93 & 0.94 & 0.95 & 0.95 & 0.96 & 0.966 & 0.994 & 0.852 \\
\hline Japan & 0.91 & 0.92 & 0.93 & 0.92 & 0.93 & 0.94 & 0.95 & 0.959 & 0.971 & 0.821 \\
\hline United Kingdom & 0.89 & 0.90 & 0.91 & 0.92 & 0.93 & 0.94 & 0.96 & 0.969 & 0.978 & 0.825 \\
\hline Finland & 0.89 & 0.91 & 0.92 & 0.92 & 0.93 & 0.94 & 0.95 & 0.964 & 0.975 & 0.823 \\
\hline France & 0.89 & 0.91 & 0.92 & 0.91 & 0.93 & 0.94 & 0.95 & 0.954 & 0.971 & 0.819 \\
\hline Switzerland & 0.92 & 0.94 & 0.94 & 0.94 & 0.95 & 0.96 & 0.97 & 0.981 & 1.000 & 0.860 \\
\hline Denmark & 0.92 & 0.93 & 0.94 & 0.95 & 0.96 & 0.96 & 0.96 & 0.973 & 0.983 & 0.831 \\
\hline Germany & 0.90 & 0.91 & 0.92 & 0.92 & 0.94 & 0.94 & 0.94 & 0.949 & 0.975 & 0.827 \\
\hline Austria & 0.91 & 0.92 & 0.93 & 0.93 & 0.95 & 0.95 & 0.96 & 0.971 & 0.989 & 0.839 \\
\hline Luxembourg & 0.97 & 1.00 & 1.00 & 1.00 & 1.00 & 1.00 & 1.00 & 1.000 & 1.000 & 0.948 \\
\hline Ireland & 0.90 & 0.93 & 0.95 & 0.96 & 0.98 & 0.99 & 1.00 & 0.994 & 1.000 & 0.843 \\
\hline Italy & 0.89 & 0.90 & 0.91 & 0.92 & 0.93 & 0.94 & 0.94 & 0.944 & 0.954 & 0.804 \\
\hline New Zealand & 0.86 & 0.88 & 0.88 & 0.88 & 0.90 & 0.90 & 0.91 & 0.922 & 0.936 & 0.790 \\
\hline Spain & 0.85 & 0.87 & 0.88 & 0.89 & 0.90 & 0.9 & 0.92 & 0.935 & 0.96 & 0.806 \\
\hline Greece & 0.82 & 0.84 & 0.85 & 0.86 & 0.87 & 0.88 & 0.90 & 0.910 & 0.944 & 0.796 \\
\hline Portugal & 0.83 & 0.85 & 0.86 & 0.87 & 0.87 & 0.87 & 0.88 & 0.888 & 0.906 & 0.763 \\
\hline Korea Rep. & 0.82 & 0.84 & 0.86 & 0.84 & 0.86 & 0.87 & 0.89 & 0.900 & 0.920 & 0.800 \\
\hline Czech Rep. & 0.80 & 0.81 & 0.82 & 0.83 & 0.84 & 0.85 & 0.88 & 0.889 & 0.916 & 0.772 \\
\hline Slovakia & 0.76 & $\mathrm{n} / \mathrm{a}$ & 0.79 & 0.80 & 0.81 & 0.82 & 0.83 & 0.846 & 0.885 & 0.758 \\
\hline Hungary & 0.77 & 0.79 & 0.80 & 0.80 & 0.82 & 0.83 & 0.86 & 0.866 & 0.874 & 0.733 \\
\hline Poland & 0.72 & 0.74 & 0.75 & 0.76 & 0.78 & 0.79 & 0.81 & 0.823 & 0.847 & 0.728 \\
\hline Mexico & 0.73 & 0.80 & 0.75 & 0.74 & 0.75 & 0.75 & 0.77 & 0.781 & 0.826 & 0.688 \\
\hline Turkey & 0.69 & 0.69 & 0.71 & 0.68 & 0.69 & 0.70 & 0.73 & 0.740 & 0.812 & 0.679 \\
\hline
\end{tabular}

Source: Human Development Reports (2000 - 2010) and www.undp.org

Table 7: GDP Index (1998-2010) 


\begin{tabular}{|c|c|c|c|c|c|c|c|c|c|c|}
\hline & 1998 & 1999 & 2000 & 2001 & 2002 & 2003 & $2004 / 5$ & $2005 / 6$ & 2007 & 2010 \\
\hline Canada & 0.585 & 0.620 & 0.660 & 0.640 & 0.620 & 0.620 & 0.660 & 0.685 & 0.700 & 0.850 \\
\hline Norway & 0.835 & 0.840 & 0.830 & 0.825 & 0.800 & 0.830 & 0.770 & 0.825 & 0.875 & 0.870 \\
\hline United States & 0.775 & 0.790 & 0.800 & 0.760 & 0.710 & 0.700 & 0.750 & 0.770 & 0.770 & 0.710 \\
\hline Australia & 0.600 & 0.640 & 0.685 & 0.665 & 0.685 & 0.700 & 0.750 & 0.755 & 0.780 & 0.790 \\
\hline Iceland & 0.865 & 0.905 & 0.930 & 0.885 & 0.835 & 0.775 & 0.880 & 0.850 & 0.885 & 0.850 \\
\hline Sweden & 0.590 & 0.720 & 0.765 & 0.800 & 0.800 & 0.755 & 0.720 & 0.650 & 0.695 & 0.690 \\
\hline Belgium & 0.560 & 0.550 & 0.650 & 0.670 & 0.635 & 0.605 & 0.580 & 0.590 & 0.625 & 0.650 \\
\hline Netherlands & 0.800 & 0.840 & 0.870 & 0.900 & 0.885 & 0.795 & 0.690 & 0.805 & 0.840 & 0.860 \\
\hline Japan & 0.795 & 0.765 & 0.765 & 0.750 & 0.730 & 0.735 & 0.780 & 0.795 & 0.805 & 0.800 \\
\hline United Kingdom & 0.685 & 0.700 & 0.725 & 0.745 & 0.740 & 0.750 & 0.760 & 0.735 & 0.735 & 0.720 \\
\hline Finland & 0.430 & 0.490 & 0.510 & 0.540 & 0.545 & 0.545 & 0.570 & 0.615 & 0.655 & 0.680 \\
\hline France & 0.415 & 0.445 & 0.525 & 0.565 & 0.550 & 0.515 & 0.500 & 0.530 & 0.585 & 0.630 \\
\hline Switzerland & 0.790 & 0.865 & 0.900 & 0.905 & 0.845 & 0.800 & 0.800 & 0.800 & 0.820 & 0.830 \\
\hline Denmark & 0.745 & 0.740 & 0.765 & 0.785 & 0.775 & 0.720 & 0.760 & 0.805 & 0.810 & 0.835 \\
\hline Germany & 0.530 & 0.585 & 0.625 & 0.635 & 0.595 & 0.545 & 0.540 & 0.580 & 0.580 & 0.625 \\
\hline Austria & 0.765 & 0.740 & 0.765 & 0.755 & 0.735 & 0.715 & 0.710 & 0.760 & 0.780 & 0.810 \\
\hline Luxembourg & 0.860 & 0.855 & 0.870 & 0.870 & 0.850 & 0.810 & 0.770 & 0.760 & 0.790 & 0.745 \\
\hline Ireland & 0.610 & 0.720 & 0.785 & 0.805 & 0.780 & 0.770 & 0.790 & 0.780 & 0.770 & 0.700 \\
\hline Italy & 0.390 & 0.425 & 0.465 & 0.520 & 0.545 & 0.560 & 0.620 & 0.660 & 0.690 & 0.665 \\
\hline New Zealand & 0.625 & 0.660 & 0.700 & 0.735 & 0.740 & 0.770 & 0.820 & 0.810 & 0.815 & 0.795 \\
\hline Spain & 0.060 & 0.205 & 0.295 & 0.475 & 0.430 & 0.435 & 0.550 & 0.575 & 0.585 & 0.435 \\
\hline Greece & 0.520 & 0.400 & 0.430 & 0.480 & 0.500 & 0.525 & 0.470 & 0.555 & 0.585 & 0.615 \\
\hline Portugal & 0.755 & 0.775 & 0.800 & 0.795 & 0.745 & 0.685 & 0.630 & 0.615 & 0.595 & 0.620 \\
\hline Korea Rep. & 0.645 & 0.685 & 0.795 & 0.815 & 0.845 & 0.830 & 0.810 & 0.825 & 0.840 & 0.850 \\
\hline Czech Rep. & 0.675 & 0.560 & 0.555 & 0.590 & 0.635 & 0.610 & 0.600 & 0.640 & 0.735 & 0.780 \\
\hline Slovakia & 0.220 & $\mathrm{n} / \mathrm{a}$ & 0.060 & 0.035 & 0.070 & 0.125 & 0.180 & 0.330 & 0.445 & 0.525 \\
\hline Hungary & 0.600 & 0.645 & 0.675 & 0.710 & 0.705 & 0.705 & 0.650 & 0.625 & 0.630 & 0.850 \\
\hline Poland & 0.470 & 0.305 & 0.195 & 0.090 & 0.005 & 0.020 & 0.110 & 0.310 & 0.520 & 0.645 \\
\hline Mexico & 0.850 & 0.870 & 0.890 & 0.875 & 0.865 & 0.875 & 0.820 & 0.840 & 0.815 & 0.800 \\
\hline Turkey & 0.670 & 0.635 & 0.680 & 0.575 & 0.485 & 0.485 & 0.500 & 0.505 & 0.560 & 0.530 \\
\hline
\end{tabular}

Source: Human Development Reports (2000 - 2010) and www.undp.org

Table 8: Unemployment Index (1998-2010) 


\begin{tabular}{|c|c|c|c|c|c|c|c|c|c|c|}
\hline & 1998 & 1999 & 2000 & 2001 & 2002 & 2003 & $2004 / 5$ & $2005 / 6$ & 2007 & 2010 \\
\hline Canada & 0.935 & 0.936 & 0.940 & 0.937 & 0.943 & 0.949 & 0.950 & 0.961 & 0.966 & 0.888 \\
\hline Norway & 0.934 & 0.939 & 0.942 & 0.944 & 0.956 & 0.963 & 0.965 & 0.968 & 0.971 & 0.938 \\
\hline United States & 0.929 & 0.934 & 0.939 & 0.937 & 0.939 & 0.944 & 0.948 & 0.951 & 0.956 & 0.902 \\
\hline Australia & 0.929 & 0.936 & 0.939 & 0.939 & 0.946 & 0.955 & 0.957 & 0.962 & 0.970 & 0.937 \\
\hline Iceland & 0.927 & 0.932 & 0.936 & 0.942 & 0.941 & 0.956 & 0.960 & 0.968 & 0.969 & 0.869 \\
\hline Sweden & 0.926 & 0.936 & 0.941 & 0.941 & 0.946 & 0.949 & 0.951 & 0.956 & 0.963 & 0.885 \\
\hline Belgium & 0.925 & 0.935 & 0.939 & 0.937 & 0.942 & 0.945 & 0.945 & 0.946 & 0.953 & 0.867 \\
\hline Netherlands & 0.925 & 0.931 & 0.935 & 0.938 & 0.942 & 0.943 & 0.947 & 0.953 & 0.964 & 0.890 \\
\hline Japan & 0.924 & 0.928 & 0.933 & 0.932 & 0.938 & 0.943 & 0.949 & 0.953 & 0.960 & 0.884 \\
\hline United Kingdom & 0.918 & 0.923 & 0.928 & 0.930 & 0.936 & 0.939 & 0.940 & 0.946 & 0.947 & 0.849 \\
\hline Finland & 0.917 & 0.925 & 0.930 & 0.930 & 0.935 & 0.941 & 0.947 & 0.952 & 0.959 & 0.871 \\
\hline France & 0.917 & 0.924 & 0.928 & 0.925 & 0.932 & 0.938 & 0.942 & 0.952 & 0.961 & 0.872 \\
\hline Switzerland & 0.915 & 0.924 & 0.928 & 0.932 & 0.936 & 0.947 & 0.947 & 0.955 & 0.960 & 0.874 \\
\hline Denmark & 0.911 & 0.921 & 0.926 & 0.930 & 0.932 & 0.941 & 0.943 & 0.949 & 0.955 & 0.866 \\
\hline Germany & 0.911 & 0.921 & 0.925 & 0.921 & 0.925 & 0.930 & 0.932 & 0.935 & 0.947 & 0.885 \\
\hline Austria & 0.908 & 0.921 & 0.926 & 0.929 & 0.934 & 0.936 & 0.944 & 0.948 & 0.955 & 0.851 \\
\hline Luxembourg & 0.908 & 0.924 & 0.925 & 0.930 & 0.933 & 0.949 & 0.945 & 0.944 & 0.960 & 0.852 \\
\hline Ireland & 0.907 & 0.916 & 0.925 & 0.930 & 0.936 & 0.946 & 0.956 & 0.959 & 0.965 & 0.895 \\
\hline Italy & 0.903 & 0.909 & 0.913 & 0.916 & 0.920 & 0.934 & 0.940 & 0.941 & 0.951 & 0.854 \\
\hline New Zealand & 0.903 & 0.913 & 0.917 & 0.917 & 0.926 & 0.933 & 0.936 & 0.943 & 0.950 & 0.907 \\
\hline Spain & 0.899 & 0.908 & 0.913 & 0.918 & 0.922 & 0.928 & 0.938 & 0.949 & 0.955 & 0.863 \\
\hline Greece & 0.875 & 0.881 & 0.896 & 0.892 & 0.902 & 0.912 & 0.921 & 0.926 & 0.942 & 0.855 \\
\hline Portugal & 0.864 & 0.874 & 0.885 & 0.896 & 0.897 & 0.904 & 0.904 & 0.897 & 0.909 & 0.795 \\
\hline Korea Rep. & 0.854 & 0.875 & 0.888 & 0.879 & 0.888 & 0.901 & 0.912 & 0.921 & 0.937 & 0.877 \\
\hline Czech Rep. & 0.843 & 0.844 & 0.885 & 0.861 & 0.868 & 0.874 & 0.885 & 0.891 & 0.903 & 0.841 \\
\hline Slovakia & 0.825 & $\mathrm{n} / \mathrm{a}$ & 0.882 & 0.836 & 0.842 & 0.849 & 0.856 & 0.863 & 0.880 & 0.818 \\
\hline Hungary & 0.817 & 0.829 & 0.883 & 0.837 & 0.848 & 0.862 & 0.869 & 0.874 & 0.879 & 0.805 \\
\hline Poland & 0.814 & 0.828 & 0.880 & 0.841 & 0.850 & 0.858 & 0.862 & 0.870 & 0.880 & 0.795 \\
\hline Mexico & 0.784 & 0.790 & 0.800 & 0.800 & 0.802 & 0.814 & 0.821 & 0.829 & 0.854 & 0.750 \\
\hline Turkey & 0.732 & 0.735 & 0.742 & 0.734 & 0.751 & 0.750 & 0.757 & 0.775 & 0.806 & 0.679 \\
\hline
\end{tabular}

Source: Human Development Reports (2000 - 2010) and www.undp.org

Table 9: Human Development Index (1998-2010) 